\title{
BUDGET INSTITUTIONS AND FISCAL POLICY IN THE U.S. STATES
}

James M. Poterba

Working Paper 5449

\author{
NATIONAL BUREAU OF ECONOMIC RESEARCH \\ 1050 Massachusetts Avenue \\ Cambridge, MA 02138 \\ February 1996
}

I am grateful to the National Science Foundation for research support, and to Steve Gold, Doug Holtz-Eakin, Sunny Ladd, and Kim Rueben for many helpful discussions. This paper, which draws on Poterba (1995a), is part of the NBER's research program in Public Economics. Any opinions expressed are those of the author and not those of the National Bureau of Economic Research.

(C) 1996 by James M. Poterba. All rights reserved. Short sections of text, not to exceed two paragraphs, may be quoted without explicit permission provided that full credit, including $($ ) notice, is given to the source. 


\title{
BUDGET INSTITUTIONS AND FISCAL POLICY IN THE U.S. STATES
}

\begin{abstract}
This paper summarizes state balanced budget requirements, and the available empirical evidence on the effect of these rules on state fiscal policies. Existing state rules differ from many current proposals at the federal level. They are typically restricted to part of the state budget, they frequently permit short term borrowing, and they lack formal enforcement mechanisms. The paper also surveys previous research on how anti-deficit provisions affect state fiscal policy. The available evidence indicates that stringent anti-deficit provisions lead to more rapid adjustment of state taxes and expenditures when fiscal deficits emerge. This suggests that changing the federal budget process has the potential to affect federal fiscal policy.
\end{abstract}

James M. Poterba

Department of Economics

E52-350

Massachusetts Institute of Technology

50 Memorial Drive

Cambridge, MA 02139-4307

and NBER 
The debate on a federal balanced budget amendment involves much speculation, but relatively little empirical evidence, on the potential effects of changes in budget institutions. The variation in budget practices across states within the United States provides a valuable source of information on the potential effects of different fiscal institutions. This paper considers the nature of balanced-budget requirements in the U.S. states, and explores what lessons, if any, the state-level experience holds for discussions of a federal balanced budget amendment. It emphasizes that most state requirements are substantially different from those currently being discussed at the federal level. In particular, virtually all states allow some types of borrowing to be used to balance the budget, at least for a single fiscal year. Most states apply balanced-budget rules to only part of their budget, and there are virtually no formal provisions for enforcing state balanced-budget rules. While these features imply that state budget rules can not provide direct evidence on the effects of the particular balanced budget rules currently under discussion at the federal level, the state evidence is relevant for assessing the broader question of whether fiscal institutions affect fiscal policy outcomes.

At the outset, it is important to recognize that studies of state differences in budget rules and fiscal policy are confounded by the potential endogeneity of budget rules. Interstate differences in balanced budget requirements may reflect differences in voter tastes for budget deficits. Fiscal institutions may therefore fail the standard exogeneity tests that are crucial for convincing policy analysis. At least some of the variation in state fiscal institutions, however, is due to historical accidents. Many states adopted anti-deficit rules as part of their state constitution, and since these 
rules are typically difficult to modify, there is an exogenous component to state fiscal rules. This component may provide a useful basis for studying the fiscal policy effects of budget rules.

Budget rules and institutions have only recently been recognized as potential determinants of tax and expenditure outcomes. Traditional public finance research directed at explaining interjurisdictional differences in taxes and expenditures has focused on variables that plausibly influence the demand for public spending, such as median income or the after-tax price of government spending facing the median resident, without considering the institutional environment. Budget institutions have been viewed as "veils" that do not affect spending outcomes. Yet the preponderance of evidence from recent empirical studies of fiscal institutions and budget outcomes suggests that tightly-drawn anti-deficit rules, especially when coupled with limits on government borrowing, reduce state deficits and affect spending and borrowing levels as well. This evidence suggests that modifying the federal budget process has the real potential to affect federal fiscal policy, even if it does not provide a direct guide to the impact of particular budget policy reforms.

\section{State Balanced Budget Rules}

Most state constitutions prohibit general operating budget deficits, but the nature and scope of these limits varies widely across states. Recent summaries of state budgeting rules, notably the National Association of State Budget Officers [NASBO] (1992) and the U.S. General Accounting Office (1993), highlight several key 
features of state balanced budget requirements.

Vermont is the only state without a balanced budget requirement of some type. Following NASBO (1992), the balanced budget requirements in the forty-nine states with such requirements can be broadly categorized into three groups, depending on the stage in the budget process at which balance is required. First, in forty-four states, the governor must submit a balanced budget. This is the weakest of the various balanced budget requirements. Second, in thirty-seven states, the legislature must enact a balanced budget. Even this more stringent rule allows actual revenues and expenditures to differ if expectations and realizations diverge. In many states that require passage of a balanced budget, the actual budget may be in deficit, and the state can borrow to carry this deficit forward to future years.

The third and strictest type of balanced budget rule combines a requirement that the legislature enact a balanced budget with a prohibition on deficit carryforward. This is the situation in $\mathbf{2 4}$ of the $\mathbf{3 7}$ states that require the legislature to enact a balanced budget. Such stringent anti-deficit rules are more common in small than large states; seven of the ten largest states allow deficits to be carried forward to subsequent years.

An important difference between existing state balanced budget rules and recent federal proposals is that state rules frequently apply to only part of the budget. The general fund, or state operating budget, is almost always subject to a balanced budget rule. NASBO (1992) classified forty-eight states as having balanced budget rules that apply to the general fund. Fewer states (34) apply such rules to special 
funds, such as funds that receive earmarked tax revenue or that are used to fund particular programs, to capital spending funds ( 33 states), and to highway and social insurance trust funds ( 30 states).

These statistics on the scope of state balanced budget rules suggest two conclusions. First, balanced budget rules typically apply to more than just the state operating budget. Second, there is substantial variation across states in the fraction of state spending that is likely to be affected by balanced budget rules. In the NASBO (1992) survey, three states reported that between 25 and 50 percent of their spending was affected by these rules, nine states reported that 50-75 percent of spending was affected, and the remaining states with balanced budget rules indicated that these rules applied to at least 75 percent of spending.

Even if a state legislature enacts a balanced budget, it is possible that during the budget cycle, which is annual in most states and bi-annual in others, the state will face the prospect of a budget deficit. State officials in this situation have three, or in some cases four, options for closing such deficits. They can raise taxes, reduce spending, change "budget execution" by altering the accounting treatment of some cash inflows or outflows, or in some cases they may be able to resort to short-term borrowing. Proponents of federal balanced budget rules typically assume that these rules will lead to tax increases or spending cuts, while skeptics argue that balanced budget targets will be met through accounting changes or various budgeting gimmicks. The state experience suggests that a wide range of accounting changes and related techniques can be used to satisfy balanced budget rules. The General 
Accounting Office's (1985) study provides several examples of the changes that were used to satisfy budgetary targets in the early 1980 s. California transferred revenues from an oil extraction royalty tax from a trust fund to the general fund; New York enacted a new payroll system to shift its last payroll payment from fiscal year 1983 into the next fiscal year; Minnesota accelerated tax collections to move receipts across fiscal years.

While some cosmetic changes are used to meet state balanced budget requirements, these changes are quantitatively less important than tax increases and spending cuts. The GAO's (1993) survey of state budgeting collected information on the dollar value of various accounting changes that states used to balance their budgets. Twenty-five states reported that they had faced prospective deficits during a recent budget enactment period. Nearly half (49 percent) of the deficit reduction was achieved through spending cuts, another 32 percent through revenue increases, and the remaining 19 percent through "other actions" such as accounting changes. In addition, 32 states reported that they had faced prospective deficits after budget enactment, and taken actions to close these deficits. Spending cuts accounted for 60 percent of the within-fiscal-year deficit reduction, revenue increases 4 percent, and "other actions" accounted for 36 percent. These "other actions" included drawing down rainy day funds (32 percent of the total deficit reduction), interfund transfers (22 percent), short term borrowing (17 percent), deferred payments (13 percent), as well as a number of other changes in budget execution. Accounting changes and related actions thus appear to account for a substantial part of fiscal adjustment 
6

within the budget cycle, but they are not the primary source of longer-term deficit reduction.

Some of the most difficult questions that arise in designing a federal balanced budget rule concern enforcement. On this point, the state experience is not terribly helpful. Gold (1992) notes that most states have no formal enforcement mechanisms for their balanced budget requirements, and the GAO (1993) reports that there have never been lawsuits to challenge state budgeting outcomes, even though there have been instances when budgets failed to balance. The GAO's (1985) survey suggested that state policy-makers view tradition, or a history of balanced budgets, as the primary factor encouraging them to maintain budget balance.

\section{Balanced Budget Rules, Taxation, and Expenditures}

Several studies have considered the effects of balanced budget rules on the size and persistence of state budget deficits, and on state tax and expenditure levels more generally. These studies suggest that fiscal institutions affect fiscal policy outcomes.

Alt and Lowry (1994) analyze data from the Census of Governments for the period 1968-1987. They model state revenues and expenditures as functions of current state income, current federal grants, lagged revenues and expenditures, the lagged difference between revenues and expenditures, and a set of indicator variables for state political circumstances. They study how fiscal policy reacts when states do run deficits, which as noted above, can happen even in states with balanced budget requirements. They find that a one dollar state deficit triggers a 77 cent response in 
the next year, through tax increase or spending reduction, for states that are Republican-controlled and prohibit deficit carryovers, compared with a 34 cent reaction in states that are Democrat-controlled and have such limits. In states that do not restrict deficit carryovers, the adjustments are 31 cents and 40 cents respectively for Republican and Democratic states. This evidence suggests that at least in some political environments, anti-deficit rules are associated with tighter fiscal policy.

Bohn and Inman (1995) explore the effect of fiscal institutions in a panel data set on forty-seven states for twenty-two years. They find that balanced budget rules that restrict end-of-year budget deficits have a statistically significant effect in reducing state general fund deficits, with an average deficit-reducing effect of approximately $\$ 100$ per capita. "Soft" constraints on proposed budgets do not affect these deficits. In the short run, deficit reduction in states with tight anti-deficit rules appears to result from lower levels of spending, not higher taxes, but over longer horizons, both taxes and spending adjust.

Poterba (1994) presents evidence on how state balanced budget rules affect the way state fiscal policies respond to unexpected deficits or surpluses. This study considers both within fiscal year adjustment as well as adjustment in the next fiscal year. It focuses on the correlation between an indicator variable for states with "weak anti-deficit rules," as classified in the Advisory Council on Intergovernmental Relations (1987), and state reactions to fiscal shocks. The results, which are based on the twenty-seven continental states with annual budget cycles, suggest that states 
with weak anti-deficit rules reduce spending less in response to unexpected deficits than do their counterparts with strict anti-deficit rules. A 100 dollar deficit overrun leads to only a 17 dollar expenditure cut in a state with a weak anti-deficit law, while it leads to a $\mathbf{4 4}$ dollar cut in states with stricter anti-deficit rules. There is no evidence that anti-deficit rules affect the magnitude of tax changes in response to unexpected deficits, either in the current or next fiscal year.

Poterba (1994) also considers the effect of state tax limitation laws on deficit adjustment. Tax limitation rules at the federal level have been discussed occasionally as part of the balanced budget debate. At the state level, these laws vary widely in their provision, and they differ from anti-deficit laws in that they limit total revenue rather than the difference between revenues and expenditures. Some tax limits constrain annual tax increases to a fixed fraction of previous taxes or of contemporaneous income growth, while others require legislative super-majorities or popular referenda to enact tax increases. States with tax limitation rules enact smaller tax increases in response to unexpected deficits than do states without such limits.

The foregoing results are concerned with the short-run effects of tax limits. They are consistent with two studies that consider the long-term effects of these limits. Crain and Miller (1990) find that taxes grew less between 1979 and 1986 in states with tax limits than in states without such limits. Rueben (1995) carefully models the endogeneity of tax limitation laws. She uses the presence or absence of state direct legislation rules as an instrumental variable for the enactment of tax limits, and finds clear evidence that tax limitation laws are correlated with slower revenue 
9

and expenditure growth during the last two decades. A number of other studies, for example Dye and McGuire (1995) and the other studies surveyed there, find that local property tax limits have real effects in reducing the growth rate of local revenues. All of these studies buttress the central conclusion that fiscal institutions have real effects on fiscal policy outcomes.

\section{Balanced Budget Rules and State Borrowing}

Limitations on borrowing are another set of fiscal institutions, besides antideficit rules and tax limitation laws, that may affect fiscal policy outcomes. States vary widely in the restrictions that are placed on the level, and potentially on the maturity, of state debt. von Hagen (1991) compares the level of state general obligation debt, per capita and relative to state income, in states with and without limits on the level of general obligation indebtedness. He finds lower general obligation debt limits, and higher levels of revenue debt and other debt that is not backed by the full faith and credit of the state, in states with strict limits. This evidence, as well as that in Bunche's (1991) study of state borrowing, suggests the possibility of using public authorities and other alternatives to state-backed borrowing to circumvent some types of limitations on fiscal policy. von Hagen also finds that the ACIR (1987) index of anti-deficit rules is negatively correlated with the level of state general obligation indebtedness; this confirms the results described above on how these rules affect fiscal policy.

Kiewiet and Szakaly (1992) present a related analysis of how anti-deficit rules 
interact with debt limits in determining state borrowing. They study whether state constitutional debt limits have any effect on the level or composition of state debt. Their primary empirical finding is that state indebtedness is negatively correlated with requirements that state debt be approved by popular referendum. This suggests that a combination of a stringent anti-deficit rule and a requirement that debt be approved by the voters is likely to bring pressure for tax increases or spending cuts, rather than debt finance, in response to state deficits.

\section{Conclusions and Interpretation}

The range of budgetary institutions across the states provides a rich opportunity to study the effects of these institutions on fiscal policy. The studies surveyed in this paper suggest that there are correlations between state balanced budget rules and state fiscal policy. Constitutional or legislative provisions that make it more costly to balance the budget in a given fashion, for example by raising taxes or by issuing longterm debt, appear to discourage these fiscal actions. Moreover, the short-run effects of anti-deficit rules seem to persist, and states that reduce spending to satisfy shortterm fiscal constraints also appear to exhibit lower levels of long-run spending.

The critical question for policy evaluation is how to interpret these correlations between budget institutions and fiscal policy outcomes. It is possible that these correlations simply reflect a correlation between fiscal discipline, fiscal institutions, and an omitted third variable, voter tastes for fiscal restraint. Voters in some jurisdictions may be less inclined to borrow to support current state outlays, or to use 
deficits to shift the burden of paying for current state programs to the future. If these voters are also more likely to support legislative or constitutional limits on deficit finance, then the observed link between fiscal rules and fiscal policy could be spurious.

It is difficult to provide definitive evidence that supports, or rejects, this view. One way to develop such evidence is include controls for state voter preferences, such as the political party of the governor or the legislature, in estimating equations for taxes or expenditures. Poterba's (1995b) study of the fiscal effects of state capital budgets, as well as many of the studies described above, pursue this approach.

A second way to address the endogeneity of fiscal institutions, pursued for example in Rueben (1995), is to draw on the history of these institutions. Many of the constitutional limits on state deficits were enacted in the nineteenth century; whether these rules reflect the preferences of current state residents is an open issue. The more difficult it is to make changes in state constitutions, the more valuable the cross-state variation is in identifying the effect of these institutions on fiscal policy.

While the potential endogeneity of budget institutions warrants caution in drawing conclusions, the available evidence suggests that changes in budget processes and in the rules affecting the dynamics of taxes and expenditures can affect fiscal policy outcomes. The view that these fiscal institutions are simply a veil, pierced by voters and their elected representatives, appears to be dominated by the richer "political economy" view suggesting that fiscal institutions mediate the link 
between voter tastes and policy outcomes. These results support the view that modifying the federal budget process may affect the level of budget deficits, and the level of federal taxes and expenditures. 


\section{REFERENCES}

Advisory Council on Intergovernmental Relations. Fiscal Discipline in the Federal

System: National Reform and the Experience of the States. Washington: Advisory Council on Intergovernmental Relations, 1987.

Alt, James E. and Robert C. Lowry. "Divided Government and Budget Deficits:

Evidence from the States." American Political Science Review 1994, 88, pp. 811-828.

Bohn, Henning, and Robert P. Inman. "Constitutional Limits and Public Deficits:

Evidence from the U.S. States." Carnegie-Rochester Conference Series on Public Policy 1995, December.

Bunche, Beverly S. "The Effect of Constitutional Debt Limits on State Governments' Use of Public Authorities." Public Choice 1991, 68, pp. 57-69.

Crain, W. Mark, and James C. Miller III. "Budget Process and Spending Growth." William and Mary Law Review 1990, 31, 1021-1046.

Dye, Richard F., and Therese J. McGuire. "The Effect of Property Tax Limitation Measures on Local Government Fiscal Behavior." Mimeo, University of Illinois, Institute of Government and Public Affairs, 1995.

Gold, Steven D. "State Government Experience with Balanced Budget Requirements: Relevance to Federal Proposals." Testimony before U.S. House of Representatives, Budget Committee, May 13, 1992.

Kiewiet, D. Roderick, and Kristin Szakaly. "The Efficacy of Constitutional Restrictions on Borrowing, Taxing, and Spending: An Analysis of State Bonded Indebtedness, 1961-90." Manuscript. Pasadena, CA: California Institute of 
Technology, 1992.

National Association of State Budget Officers. State Balanced Budget Requirements:

Provisions and Practice. Washington: National Association of State Budget Officers, 1992.

Poterba, James M. "State Responses to Fiscal Crises: The Effects of Budgetary Institutions and Politics." Journal of Political Economy 1994, 102, pp. 799821.

Poterba, James M. "Balanced Budget Rules and Fiscal Policy: Evidence From the States." National Tax Journal 1995a, 48, pp. 329-337.

Poterba, James M. "Capital Budgets, Borrowing Rules, and State Capital Spending." Journal of Public Economics 1995b, 56, pp. 165-187.

Rueben, Kim S. "Tax Limitations and Government Growth: The Effect of State Tax and Expenditure Limits on State and Local Government." Mimeo, MIT Department of Economics, 1995.

U.S. General Accounting Office. Budget Issues: State Balanced Budget Practices. GAO/AFMD-86-22BR. Washington: General Accounting Office, 1985.

U.S. General Accounting Office. Balanced Budget Requirements: State Experiences and Implications for the Federal Government. GAO/AFMD-93-58BR. Washington: General Accounting Office, 1993.

von Hagen, Jurgen. "A Note on the Empirical Effectiveness of Formal Fiscal Restraints." Jeurnal of Public Economics 1991, 44, pp. 199-210. 